\title{
Development and Evaluation of Unidirectional Mucoadhesive Bio-Flexy Films Loaded with Nanosized Topiramate using a Novel Biopolymer from Glycine max
}

\author{
Sugandha Varshney ${ }^{1, *}$, N V Satheesh Madhav ${ }^{2}$ \\ ${ }^{1}$ Kingston Imperial Institute of Technology and Sciences, Dehradun, Uttarakhand, INDIA. \\ ${ }^{2}$ Formulation Research Development, Vital Therapeutics and Formulations, Pvt. Ltd., Telangana, 500003, INDIA.
}

\begin{abstract}
Aim: Formulation and evaluation of nanosized Topiramate loaded bio-flexy films using novel biopolymer isolated from Glycine max seeds for epilepsy treatment. Methods: Formulations containing nanosized Topiramate: Glycine max biopolymer (in ratios of $1: 0.5,1: 1 ; 1: 3,1: 5,1: 6,1: 10)$ (FGO1-FGO6) were prepared by solvent casting method. Results: Glycine max biopolymer showed percentage yield: $81.06 \% \pm 0.01$, light yellow, odorless, soluble in chloroform, water and color changing point: $218^{\circ} \mathrm{C} \pm 2$. Topiramate loaded bio-flexy films containing Glycine max biopolymer (FGO1-FGO6) revealed Thickness: $0.019 \mathrm{~mm} \pm 0.012$ to $0.037 \mathrm{~mm} \pm 0.010$, Surface $\mathrm{pH}: 7.01 \pm 0.03$ to $7.01 \pm 0.02$, ex-vivo Mucoadhesion Time: $30-120$ mins, ex vivo Mucoretention Time:90-210 mins, Weight Uniformity: $0.078 \pm 0.05$ to $0.083 \pm 0.04$, Drug Content Uniformity: $72.7 \% \pm 0.50$ to $82.84 \% \pm 0.48$, Folding Endurance: 117-173, Swelling Percentage: $62 \% \pm 0.6$ to $74 \% \pm 0.4$, Percentage Moisture Uptake (PTU): $2.0 \% \pm 0.13$ to $2.8 \% \pm 0.12$. The drug release pattern based on the $\mathrm{T} 50 \%$ and $\mathrm{T} 80 \%$ was found to be FGO2 $(1: 1)>$ FGO6 $(1: 10)>$ FGO1 $(1: 0.5)>$ FGO4 $(1: 5)>$ FGO5 (1:6) $>$ FGO3 (1:3). Conclusion: Based on all the evaluation parameters, FGO2 (containing Topiramate: Glycine max biopolymer (1:1)) Bio-flexy film having $\mathrm{R}^{2}=0.9139$, Higuchi Matrix as best fit model, follows Fickian Diffusion (Higuchi Matrix) release mechanism, T50\%: $25 \mathrm{hr}$., T80\%: 27 hr. Prepared formulations were suitable for Soft Palatal Delivery.
\end{abstract}

Key words: Unidirectional, Mucoadhesive, Bio-flexy films, Nanosized Topiramate, Soft Palate, Glycine max biopolymer.

\section{INTRODUCTION}

Epilepsy, a chronic neurological disorder occurs due to excess of excitatory neurotransmitter discharges in brain. Every year 2.4 million people are diagnosed with epilepsy. $70 \%$ of Epilepsy patients are responsive to Antiepileptic medications. ${ }^{1}$ Antiepileptic drug, Topiramate possesses half-life of 19-30 hr; bioavailability: of 80\%; protein binding of $13-17 \%$; water solubility of $9.8 \mathrm{mg} / \mathrm{L}$. It is used for Partial Onset and Generalized Onset Seizures. It augments the activity of neurotransmitter GammaAmino Butyrate (GABA) at subtypes of $\mathrm{GABA}_{\mathrm{A}}$ Receptor. Soft palate is part of oral mucosa, constitutes back of roof of mouth. Soft palatal drug delivery provides sustained and controlled drug delivery. It has non-keratinized histology no bone, abundant blood and nerve supply, drug directly reaches systemic circulation, non-invasive, non-mobile with high mucoretention ability, afford high bioavailability, lower doses, offers a Novel mucoadhesive Drug Delivery Platform for Brain targeting. It is a promising area for systemic delivery of orally inefficient drugs, potent peptide and protein drug molecules. Trigeminal nerve directly connects soft palate to brain. Thus, drug
Submission Date: 03-08-2019; Revision Date: 09-11-2019; Accepted Date: 26-02-2020

DOI: 10.5530/ijper.54.3.111 Correspondence: Dr. Sugandha Varshney Kingston Imperial Institute of Technology and Sciences, Dunga Road, Manduwala, Kanswali Kodari, Dehradun-248007, Uttarakhand, INDIA. Phone: +916396706694 E-mail: sugandhavarshney19.12.86@gmail.com

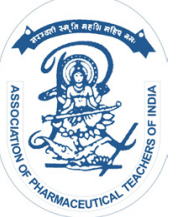

www.ijper.org 
in Nanosized form directly reaches into brain through inter and intra neural route. Since it lacks taste buds, bitter tasting drugs can be administered by this route. The soft palatal mucosa possesses unique inbuilt characteristics of not interfering with patient's regular routine activities of talking, eating, drinking, non-interference of tongue It is innervated by Mandibular branch of trigeminal nerve, Greater palatine nerve, Nasopalatine nerve, Lesser palatine nerve, Motor nerves, Glossopharyngeal nerve, as well as Greater Palatine branch of Maxillary Artery, Ascending Palatine branch of Facial Artery, Middle Meningeal artery, Ascending pharyngeal artery, Accessory Meningeal artery. It has Thickness: 158-224 $\mu \mathrm{m}, \mathrm{pH}: 7.34 \pm 0.38$, Blood flow: $0.89 \mathrm{~mL} /$ $\mathrm{min} / \mathrm{cm}$, Surface area: $200 \mathrm{~cm}^{2} ., 3$ In this research work, an inert, biodegradable cost effective biopolymer bioexcipient isolated from Soybean seeds, legumes obtained from plant Glycine max belonging to Family Fabaceae. It contains Minerals like Calcium-28\%, Iron-121\%, Manganese-120\%, Magnesium-79\%, Phosphorus, Potassium-38\%, Zinc-51\%, Phytic Acid, Carbohydrates-30\%, Protein-36.49\%, Dietary Fiber-37\%, Total Fat-20\%, Omega-3 fatty acid, Omega- 6 fatty acid, B Vitamins, including Folate $-94 \%$, Vitamin C-7\%, Vitamin E-6\%, Vitamin K-45\% ${ }^{4}$ Bio-flexy films were prepared by economical method of solvent casting. Various evaluation parameters were performed for screening of prepared Bio-flexy films formulations. The optimized formulations showing $\mathrm{t}_{1 / 2}$ of more than 90 hrs were selected as best formulations.

\section{MATERIALS AND METHODS}

DRUG: Topiramate (procured from Cipla Ltd, Mumbai)

POLYMERS: Soyabean seeds procured from local market. Sodium Carboxyl Methyl Cellulose (Central drug House (P) Ltd. New Delhi) all other reagents used were of highest purity and analytical grade. Double distilled water was used throughout the experimental work.

\section{Isolation of biomaterial from Glycine max}

Procured Soyabean powder from local market. To 120 gm. of sieved Soyabean seeds powder, added $120 \mathrm{~mL}$ Chloroform. Sonicated mixture for 3 mins. Centrifuged at $3500 \mathrm{rpm}$ for $15 \mathrm{~min}$. Separated supernatant. Residual portions of mixture refrigerated for $24 \mathrm{hr}$ s. Isolated Biomaterial was collected, naturally dried for $24 \mathrm{hr}$. Pass through Sieve No. 120. Optimized, calculated \% yield. Stored in well closed container for further use.

\section{Physicochemical Characterization of isolated Biomateria| ${ }^{6,7}$}

The isolated bio-material was characterized for physicochemical parameters such as odor, color, melting point, solubility along with chemical tests.

(a) Texture, (b) Color, (c) Odor were examined physically.

(d) Color Changing Point: Determined by capillary method by Melting point apparatus. The Bio-polymer was kept in a capillary tube and it was fitted in a Melting point apparatus. Temperature was determined by thermometer.

(e) Solubility: Determined in chloroform, methanol, distilled water, acetone.

(f) Test for carbohydrates: Molisch Reagent Test: 2 $\mathrm{mL}$ of biopolymer solution ( $0.1 \mathrm{gm}$ dissolved in $2 \mathrm{~mL}$ of distilled water) was taken in a test tube. Added 2 drops of Molisch reagent (Solution of $\alpha$-naphthol in 95\% Ethanol). Concentrated sulphuric acid $(2 \mathrm{~mL})$ was taken in a test tube and biopolymer solution was gradually poured over it leading to the formation of two separate layers. Change in color was observed.

(g) Test for proteins: Biuret Test: Determines the presence of peptide bonds in protein content in isolated biomaterial. In a test tube, $2 \mathrm{~mL}$ of biomaterial solution ( $0.1 \mathrm{gm}$. Biopolymer dissolved in $2 \mathrm{~mL}$ of distilled water) was taken. Added $1 \mathrm{~mL}$ of sodium hydroxide solution $(1 \%)$ and $1 \%$ of copper (II) sulphate solution to above biomaterial solution drop wise. Allowed the mixture to stand for 5 mins and observed the color change.

(h) Test for starch: Added 2 drops of Iodine solution to a test tube containing $2 \mathrm{~mL}$ of biopolymer solution ( $0.1 \mathrm{gm}$. Biopolymer dissolved in $2 \mathrm{~mL}$ of distilled water) observed the change in color.

(i) Test for reducing sugar: Incorporated $1 \mathrm{~mL}$ of Fehling's A and $1 \mathrm{~mL}$ of Fehling's B solutions to a test tube containing $2 \mathrm{~mL}$ of biopolymer solution ( $0.1 \mathrm{gm}$. Biopolymer dissolved in $2 \mathrm{~mL}$ of distilled water). Heated at $60^{\circ} \mathrm{C}$ for few mins and observed change in color.

\section{Spectral studies of isolated biopolymer ${ }^{6,7}$}

IR Spectroscopy by $\mathrm{KBr}$ Disc Method. $1 \mathrm{mg}$ of isolated biopolymer was incorporated with $100 \mathrm{mg}$ of Potassium Bromide in mortar to form pellet by applying pressure of 10 tons. Recorded IR Spectra. Similarly recorded IR spectra of pure Topiramate.

DSC (Differential Scanning Calorimetry) using Perkin Elmer Instrument of Model-JADE DSC: Heat flow: $50-250^{\circ} \mathrm{C}$, rate: $10^{\circ} \mathrm{C} / \mathrm{min}$ and Nitrogen flow 
rate: of $20 \mathrm{~mL} / \mathrm{mins}$. DSC Spectra of biopolymer as well as that of pure Topiramate was recorded.

NMR (Nuclear Magnetic Resonance) Spectral Analysis: Solvent: Dimethyl Sulfoxide), flow cell: 5 $\mathrm{mm}$ diameter. High flow rates were applied to sample. The flow cell in the instrument was rinsed again with the reaction mixture when the valve switches back. Recorded the Spectra.

\section{SEM Analysis}

Morphological examination of surface and internal structure of the biomaterial was performed by using scanning electron microscope. A small amount of biomaterial was fixed on aluminum studs, was coated with gold using a sputter coater under vacuum (pressure: 1 $\mathrm{mm} \mathrm{Hg}$ ).

\section{Cell-Line Toxicity Study of Biopolymer (MTT Cytotoxicity Assay using H9c2 cell line (cardiac cells)}

The viable cells reduces MTT [3-(4, 5-Dimethyl Thiazol-2-yl)-5-Diphenyl Tetrazolium Bromide] to purple colored water-insoluble product Formazan using "Succinate-tetrazolium reductase" system. Being impermeable, it gets accumulated within the healthy cells. It is solubilized by Dimethyl Sulphoxide (DMSO). Recorded optical density (OD) at $590 \mathrm{~nm} .^{8}$

\section{In vitro Mucoadhesivity of Isolated Biopolymer}

Determined by Modified Shear Stress Apparatus by placing different concentrations $1 \%, 2 \%, 4 \%, 6 \%, 8 \%$ and $10 \%$ of biopolymer solutions in between the two glass plates. In-vitro Adhesive Strength as determined by measuring the weight required to break adhesive bonds between the isolated biomaterial and the glass plate from $0-30 \mathrm{~min}$.

\section{Standard Graph of Drug ${ }^{9,10}$}

\section{(a) Preparation of Standard Curve of Topiramate in Distilled Water}

Topiramate does not contain intrinsic chromophore, thus it cannot be analysed by ultraviolet, visible or fluorescence absorption without pre-treatment. A method was developed for Topiramate by the reacting it with Ammonium Molybdate as chromogenic agent in presence of 2M Hydrochloric Acid. 1, 2,3,4,5 mL of Standard drug solutions $(10-50 \mu \mathrm{g} / \mathrm{mL}$ drug solution) was transferred in five $10 \mathrm{~mL}$ volumetric flasks. Added $2 \mathrm{ml}$ of $5 \%$ of Ammonium Molybdate followed by $2 \mathrm{~mL}$ of $2 \mathrm{M}$ hydrochloric acid to above solutions. Made up the volume up to $10 \mathrm{~mL}$ with Distilled Water. Heated the reaction mixture in water bath for 35 mins at $50^{\circ} \mathrm{C}$ until full blue colour was developed. Measured the absorbance against blank.

\section{(b) Preparation of Standard Graph of Topiramate in Phosphate Buffer of $\mathrm{pH} 7.4$}

Dissolved $10 \mathrm{mg}$ of Topiramate in $30 \mathrm{~mL}$ of Phosphate Buffer ( $\mathrm{pH}$ 7.4) taken in a $100 \mathrm{~mL}$ volumetric flask. Made up the volume up to the mark with Phosphate Buffer $(100 \mu \mathrm{g} / \mathrm{mL})$. Prepared dilutions of Concentrations $(1,2,3,4,5,8,10,20,30,40,50 \mu \mathrm{g} / \mathrm{mL})$ in $10 \mathrm{~mL}$ volumetric flasks. Absorbance was measured at $\lambda_{\text {max }}=244$ nm against solvent blank.

\section{Drug Biopolymer Interaction Studies ${ }^{10}$}

Topiramate: isolated Glycine max biopolymer in ratios of 1:1, 1:3 and 3:1 were taken. Measured Absorbance and compared with pure Topiramate.

a) Dry method: Topiramate: Glycine max biomaterial in above mentioned ratios were taken in dry form in three petridishes. Kept for two hours at room temperature. Diluted the mixtures with $2 \mathrm{~mL}$ of Methanol. Absorbance was measured, observed shift in $\lambda_{\text {max }}$ in comparison with pure drug and reported.

b) Wet method: Topiramate: Glycine max biomaterial in above mentioned ratios were taken in dry form in three petridishes $1 \mathrm{~mL}$ of distilled water was added in each petridish. Dried in oven for $30 \mathrm{mins}$ at $50^{\circ} \mathrm{C}$. Diluted with $2 \mathrm{~mL}$ of Methanol. Absorbance was measured, observed shift in $\lambda_{\max }$ in comparison with pure drug and reported.

c) Colorimetry Method: Topiramate: Glycine max in ratio of 1:1 were mixed with Potassium Permanganate on glass plate. Observed color change, diluted suitably with distilled water, analyzed by UV. Repeated with Drug: Distilled Water and Drug: Potassium Permanganate.

\section{Nanosizing of Drug}

1. Solvent Evaporation Method: Admixed $100 \mathrm{mg}$ Topiramate with, $10 \mathrm{mg}$ of Dextrose, $5 \mathrm{mg}$ of Fructose and $10 \mathrm{~mL}$ of Methanol in mortar pestle. Sonicated mixture for up to 5 cycles (each cycle of 180 secs). Diluted with $50 \mathrm{~mL}$ distilled water and further sonicated up to 15 cycles. Absorbance, \% Transmittance, \% Blockage (100 - \% Transmittance) was measured after every 5 cycles. Dried the residue. ${ }^{11}$

2. Sonication method: Admixed $100 \mathrm{mg}$ Topiramate with, $10 \mathrm{mg}$ of Dextrose, $5 \mathrm{mg}$ of Fructose and $10 \mathrm{~mL}$ of Distilled Water in mortar pestle. Sonicated mixture for up to 5 cycles (each cycle of 180 secs). Diluted with $50 \mathrm{~mL}$ distilled water and further sonicated up to 15 cycles. Absorbance, $\%$ Transmittance, $\%$ Blockage (100 
- \% Transmittance) was measured after every 5 cycles. Dried the residue. ${ }^{11}$

\section{Permeation Study of Topiramate using M.S. Apparatus}

Nanosized Topiramate $(10 \mathrm{mg})$ was added in Donor compartment. Filled Phosphate Buffer of $\mathrm{pH} 7.4$ in Receiver compartment. Egg Shell Membrane was tied over donor compartment. Study was conducted for up to $48 \mathrm{hr}$. Nanosized Drug would permeate through egg membrane into Phosphate Buffer. At specific time intervals ranging from $10 \mathrm{~min}$ up to $48 \mathrm{hr}$, samples of 5 $\mathrm{mL}$ were withdrawn and immediately restored with the same volume of fresh phosphate buffer. Measured the absorbance in U.V spectrophotometer at $244 \mathrm{~nm}$ and assessed the amount of drug permeated. Compared with that of control i.e., without nanosized drug and reported.

\section{Solvent Casting Method as formulation technique of Bio-flexy Films}

Nanosized Topiramate (Anticonvulsant) (100 mg) was triturated with $50 \mathrm{mg}$ of biopolymer (Mucoadhesive, film forming cum retarding agent) (in ratio of 1:0.5) for $2 \mathrm{~min}$ using pestle mortar. Added $10 \mathrm{~m}$ of Distilled
Water (Solvent). To this dispersion, incorporated $10 \mathrm{mg}$ of Dextrose (Flexicizer), $5 \mathrm{mg}$ of Fructose (Flexicizer) and $10 \mu \mathrm{L}$ of Glycerine ( $1 \%$ solution v/v) (Plasticizer) with continuous stirring. $0.6 \mathrm{gm}$. of Pectin (Film Initiator) was added. Mixture was further uniformly triturated for $5 \mathrm{~min}$. Made up the volume up to $20 \mathrm{~mL}$ using Distilled water. Subjected the mixture to magnetic stirring for $15 \mathrm{~min}$. Sonicated up to 5 cycles (each cycle $3 \mathrm{~min}$ ). Clear dispersion obtained was poured into petridish. Kept for drying at room temperature for 24 hr. Removed prepared nanosized drug loaded Bio-flexy film from petridish. Similarly, six different formulations of nanosized Topiramate with different isolated biopolymers and Standard Sodium Carboxyl Methyl Cellulose Polymer in different ratios of 1:1, 1:3, 1:5, 1:6 and 1:10 were prepared. ${ }^{12}$ (Tables 1,2 )

\section{Evaluation of Formulated Bio-flexy Films ${ }^{12,13}$}

Thickness: Determined the average thickness of formulations by standard digital micrometer and reported with appropriate standard deviation.

Surface pH study: The formulations were immersed in $1 \mathrm{ml}$ of distilled water for $1 \mathrm{hrs}$ at room temperature. Measured $\mathrm{pH}$ using $\mathrm{pH}$ meter in triplicate and reported the avg. values.

\begin{tabular}{|c|c|c|c|c|c|c|}
\hline Formulation & $\begin{array}{l}\text { FGO1 } \\
(1: 0.5)\end{array}$ & $\begin{array}{c}\text { FGO2 } \\
(1: 1)\end{array}$ & $\begin{array}{c}\text { FGO3 } \\
(1: 3)\end{array}$ & $\begin{array}{c}\text { FGO4 } \\
(1: 5)\end{array}$ & $\begin{array}{c}\text { FGO5 } \\
(1: 6)\end{array}$ & $\begin{array}{l}\text { FGO6 } \\
(1: 10)\end{array}$ \\
\hline Nanosized Topiramate (mg) & 100 & 100 & 100 & 100 & 100 & 100 \\
\hline Glycine max biopolymer (mg) & 50 & 100 & 300 & 500 & 600 & 1000 \\
\hline Dextrose (mg) & 10 & 10 & 10 & 10 & 10 & 10 \\
\hline Fructose (mg) & 5 & 5 & 5 & 5 & 5 & 5 \\
\hline Glycerine $(\mu \mathrm{l})$ & 10 & 10 & 10 & 10 & 10 & 10 \\
\hline Pectin (gm.) & 0.6 & 0.6 & 0.6 & 0.6 & 0.6 & 0.6 \\
\hline Distilled Water $(\mathrm{mL})$ & 20 & 20 & 20 & 20 & 20 & 20 \\
\hline
\end{tabular}

Table 2: Formulation of Nanosized Topiramate loaded Flexy Films using Sodium Carboxyl Methyl Cellulose Standard Polymer.

\begin{tabular}{|c|c|c|c|c|c|c|}
\hline Formulation & $\begin{array}{c}\text { FEO1 } \\
(\mathbf{1 : 0 . 5 )}\end{array}$ & $\begin{array}{c}\text { FEO2 } \\
(\mathbf{1 : 1 )}\end{array}$ & $\begin{array}{c}\text { FEO3 } \\
\mathbf{( 1 : 3 )}\end{array}$ & $\begin{array}{c}\text { FEO4 } \\
\mathbf{( 1 : 5 )}\end{array}$ & $\begin{array}{c}\text { FEO5 } \\
\mathbf{( 1 : 6 )}\end{array}$ & $\begin{array}{c}\text { FEO6 } \\
\mathbf{( 1 : 1 0 )}\end{array}$ \\
\hline Nanosized Topiramate (mg) & 100 & 100 & 100 & 100 & 100 & 100 \\
\hline $\begin{array}{c}\text { Sodium Carboxyl Methyl Cellulose } \\
\text { standard polymer (SCMC) } \mathbf{( m g )}\end{array}$ & 50 & 100 & 300 & 500 & 600 & 1000 \\
\hline Dextrose (mg) & 10 & 10 & 10 & 10 & 10 & 10 \\
\hline Fructose (mg) & 5 & 5 & 5 & 5 & 5 & 5 \\
\hline Glycerine (j) & 10 & 10 & 10 & 10 & 10 & 10 \\
\hline Pectin (gm.) & 0.6 & 0.6 & 0.6 & 0.6 & 0.6 & 0.6 \\
\hline Distilled Water $(\mathbf{m L})$ & 20 & 20 & 20 & 20 & 20 & 20 \\
\hline
\end{tabular}




\section{Ex-vivo Mucoadhesion Study of Formulations by Rotating Cylinder Method}

Evaluated the Mucoadhesivity of Bio-flexy Films formulations using goat intestinal mucosa

(i.e., Capra aegagrus). $1 \mathrm{~cm}^{2}$ of each formulation were cut and applied over the inner surface of goat intestinal mucosa tied on rotating basket of I-Dissolution Apparatus. Dissolution media volume: $900 \mathrm{~mL}$ of buffer of $\mathrm{pH} 7.4$ in each dissolution bath, temperature: $37^{\circ} \mathrm{C}$, rotation: $50 \mathrm{rpm}$. Observed and reported the dislodgement and detachment of films from mucosal surface.

\section{Ex-vivo Mucoretention Study of Formulations}

Evaluated the Mucoadhesivity of Bio-flexy Films formulations using goat intestinal mucosa

(i.e., Capra aegagrus). $1 \mathrm{~cm}^{2}$ of each formulation were cut and applied over the inner surface of goat intestinal mucosa tied on slanting condenser. Buffer of $\mathrm{pH}$ 7.4 was allowed to flow from a burette. Observed and reported the dislodgement and detachment of films from mucosal surface.

\section{Weight Uniformity of formulated nanosized drugs loaded Bio-Flexy Films}

10 formulations of $1 \mathrm{~cm}^{2}$ diameter were weighed. Average weight were determined and reported.

\section{Drug Content Uniformity of formulated nanosized drugs loaded Bio-Flexy Films}

Dissolved the films in $100 \mathrm{~mL}$ of Phosphate Buffer of pH7.4 up to $24 \mathrm{hr}$. Occasionally shook the solution and then diluted $5 \mathrm{~mL}$ of solution 4 up to $20 \mathrm{~mL}$ with phosphate buffer. Filtered and determined the drug content using UV analysis at $\lambda_{\text {max }}$ of $750 \mathrm{~nm}$.

\section{Folding Endurance of formulated nanosized drugs loaded Bio-Flexy Films}

Obtained by folding the formulations from each Drug: Biopolymer ratio multiple times at the same place until they broke.

\section{Swelling Percentage Study of formulated nanosized drugs loaded Bio-Flexy Films}

Formulations of $1 \mathrm{x} 1 \mathrm{~cm}^{2}$ size were weighed taken in petridish. Added distilled water10 $\mathrm{mL}$. Reweighed the films after $1 \mathrm{hr}$. Water was absorbed by films which caused their swelling and increase in weights. Repeated after $24 \mathrm{hr}$. Calculated \% Swelling Index and reported.

Percentage Moisture Uptake (PMU) of formulated nanosized drugs loaded Bio-Flexy Films

Placed the formulations $(1 \mathrm{~cm}$ diameter) in saturated solution of aluminum chloride in desiccator. Maintained at $79.5 \%$ humidity. After 2 days the films were removed. Weighed the films. Percentage Moisture Absorption was calculated and reported.

Percentage Moisture Uptake $=($ Final weight of Films-Initial weight of films $) \times 100$ Initial weight of Films

In-vitro Drug Release Study of Formulated Nanosized Drugs Loaded Bio-flexy Films using Modified M.S. in-vitro Diffusion Apparatus.

Filled 36 vials (receiver compartment) with buffer of $\mathrm{pH}$ 7.4. Kept the vials in thermostatically controlled compartment. Egg membranes were tied to Donor compartment (containing formulations). Inserted donor compartments into receiver compartments. Maintained temperature at $37^{\circ} \mathrm{C}$ using orbital shaker incubator. Samples were taken at regular intervals from 10 min up to $48 \mathrm{hr}$. Replaced buffer completely after every sampling. Performed Ultraviolet Spectral analysis of each sample.

\section{Stability Studies of Formulations as per ICH Guidelines (Q1B)}

Performed stability studies of Bio-flexy films at varying conditions of temperature and relative humidity i.e., $40^{\circ} \mathrm{C} \pm 2{ }^{\circ} \mathrm{C}$ with $\pm 45 \pm 5 \% \mathrm{RH}$, at $25 \pm 2{ }^{\circ} \mathrm{C}$ with 60 $\pm 5 \% \mathrm{RH}$ and at $2 \pm 5^{\circ} \mathrm{C}$ for up to 3 months. Change in $\mathrm{pH}$, Folding Endurance, in-vitro Drug Release were observed and reported.

\section{RESULTS AND DISCUSSION}

\section{Yield of Isolated Biopolymer}

Biopolymer was isolated from natural edible source of Glycine max by simple and economical method. The isolated biopolymer was optimized repeatedly for six times. Calculated and reported \% yield. The \% yield of Glycine $\max$ biopolymer was found to be $81.06 \% \pm 0.01$.

\section{Physico-chemical Properties of Isolated Biomaterial}

The biomaterial obtained from the seeds of Glycine max and showed following characteristics: (a) Texture: Powder; (b) Color: Light Yellow; (c) Odor: Odorless; (d) Solubility: Soluble in methanol, acetone; (e) Color Changing Point: $218^{\circ} \mathrm{C} \pm 2$.

(f) Molisch Reagent test for Carbohydrates: Purple color appeared at interface of two layers because of formation of 5-hydroxy methyl furfural. This indicated presence of carbohydrates.

(g) Biuret test for Proteins: Change in color was observed as $\mathrm{Cu}$ (II) ions formed a chelate complex of violet color which absorbed light at $540 \mathrm{~nm}$. This confirmed the presence of Proteins. 
(h) Starch Test: Intense blue black color did not appeared confirmed the absence of Starch in isolated biomaterial.

(i) Test for Reducing Sugar: Appearance of brick red precipitate indicated reducing sugar.

\section{Spectral Studies of Isolated Biopolymer}

\section{IR Spectroscopy}

IR Spectroscopy was performed for the isolated biomaterial to determine the presence of Functional Groups in biopolymer. IR Peaks of Glycine max biopolymer were obtained at $1408 \mathrm{~cm}^{-1}, 3175 \mathrm{~cm}^{-1}, 3028 \mathrm{~cm}^{-1}, 1624$ $\mathrm{cm}^{-1}, 3904 \mathrm{~cm}^{-1}$ which indicated functional groups $\mathrm{S}=\mathrm{O}$, $\mathrm{RCOOH}, \mathrm{C}=\mathrm{C}-\mathrm{CO}-\mathrm{OH}, \mathrm{RCONH}_{2}, \mathrm{RCH}_{2} \mathrm{OH}$. (Figure 1)

\section{Differential Scanning Calorimetery (DSC)}

DSC Peak of Glycine max biopolymer was obtained at $91.74^{\circ} \mathrm{C}$, Peak Height was $4.5310 \mathrm{~mW}$, Delta $\mathrm{H}$ was $279.7280 \mathrm{~J} / \mathrm{g}$, Onset depicted boiling point at $48.17^{\circ} \mathrm{C}$ and Glass Transition temperature was $137.82^{\circ} \mathrm{C}$. (Figure 2).

\section{Nuclear Magnetic Resonance Spectroscopy (NMR)}

${ }^{1}$ HNMR Spectra of Glycine max biopolymer revealed carbohydrates residue as indicated by the shift of carbohydrate protons at 3-6 ppm when compared reflected the peak at $5.45 \mathrm{ppm}$. (Figure 3)

\section{Scanning Electron Microscopy (SEM) of Isolated Biopolymer}

SEM image of Glycine max biopolymer showed size range of $100 \mu \mathrm{m}$, irregular structure and uneven flakes. (Figure 4)

Cell-Line Toxicity Study Data of Isolated Polymer Cell-line toxicity data of Glycine max biopolymer in concentrations of $31.25-500 \mu \mathrm{M}$ showed $\mathrm{IC}_{50}(\mu \mathrm{M})$ of 55.8705 along with mean $\%$ cell viability of almost

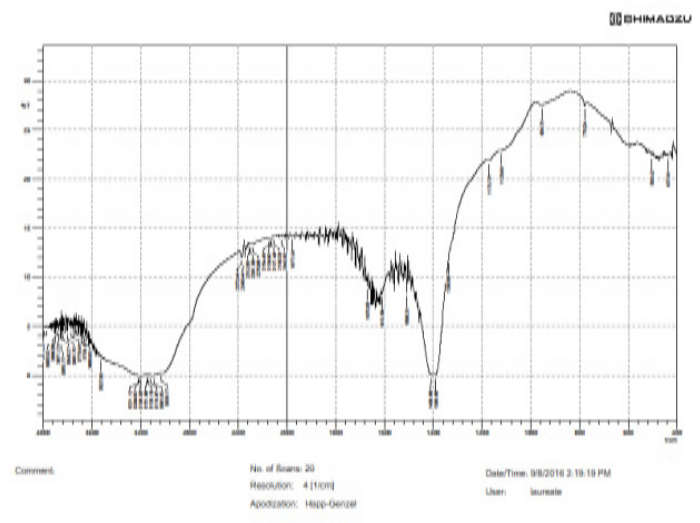

Figure 1: IR Spectra of Glycine max biopolymer.
$100 \%$. Hence isolated Glycine max biopolymer was safe and non-toxic. (Figure 5)

\section{In-vitro Mucoadhesivity of Isolated Biopolymers by Shear Stress Method}

Order of Mucoadhesivity of all concentrations of Glycine max biopolymer was $10 \%$ Glycine max biopolymer $>8 \%$ Glycine max biopolymer $>6 \%$ Glycine max biopolymer $>4 \%$ Glycine max biopolymer $>2 \%$ Glycine max biopolymer $>1 \%$ Glycine max biopolymer. (Table 3)

\section{Spectral Studies of pure Topiramate}

\section{IR Spectra of Topiramate}

IR Peaks of Topiramate were obtained at $240 \mathrm{~cm}^{-1}, 352$ $\mathrm{cm}^{-1}, 928 \mathrm{~cm}^{-1}, 1022 \mathrm{~cm}^{-1}, 1102 \mathrm{~cm}^{-1}$, which indicated functional groups at $\mathrm{CH}_{3}, \mathrm{SO}_{3}, \mathrm{CH}_{2}, \mathrm{C}=\mathrm{O}, \mathrm{NH}_{2}$ respectively. (Figure 6)

\section{DSC Spectra of Topiramate}

DSC Peak of Topiramate was obtained at $122.41^{\circ} \mathrm{C}$, Delta $\mathrm{H}$ at $-95.56 / \mathrm{g}$, the endothermic peak at $178^{\circ} \mathrm{C}$ is due to first stage of decomposition, where Topiramate loses its sulfamate group, preceding mass loss (Figure 7).

\section{Standard Graphs of Topiramate}

(a) Standard Graph of Topiramate in Distilled Water: The Standard Curve of Topiramate showed range of linearity from 10 to $50 \mu \mathrm{g} / \mathrm{ml}$ at $750 \mathrm{~nm} \lambda_{\text {max }}$. $R^{2}$ value was found to be 0.9994. (Figure 8 (a))

(b) Standard Graph of Topiramate in Phosphate Buffer pH 7.4: The Standard Curve of Topiramate showed linearityat $\lambda_{\text {max }}$ of $244 \mathrm{~nm} . \mathrm{R}^{2}$ value was found to be 0.9945 . (Figure 8(b))

\section{Drug-polymer interaction study of the isolated biopolymer}

(1) Wet method: No drug-excipient interaction occurred as there was no significant difference in

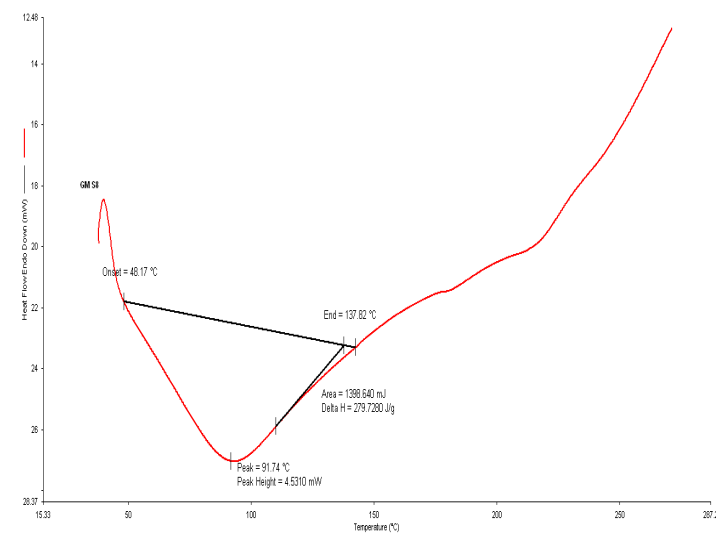

Figure 2: DSC Spectra of Glycine max biopolymer. 
$\lambda_{\max }$ at $752 \mathrm{~nm}$ as compared to pure Topiramate at 750 nm.

(2) Dry method: No drug-excipient interaction occurred as there was no significant difference in

$\lambda_{\max }$ at $752 \mathrm{~nm}$ as compared to pure Topiramate at 750 $\mathrm{nm}$

Colorimetry: Drug showed color change from pink to brown with Potassium Permanganate while polymer showed no color change. No significant difference in shift of $\lambda_{\text {max }}$ than that of pure drug observed.

Nanosizing of Topiramate: (Figure 9)

\section{Permeation Study of Topiramate}

Permeation study of pure and nanosized Topiramate using M.S. Apparatus revealed that nanosized Topiramate permeated more through egg membrane than pure Topiramate. (Figure 10)

\section{Evaluation Parameters of Formulations \\ Thickness of Formulated Bio-flexy Films}

As polymer concentration was increased, thickness of films increased proportionately. The thickness of for-

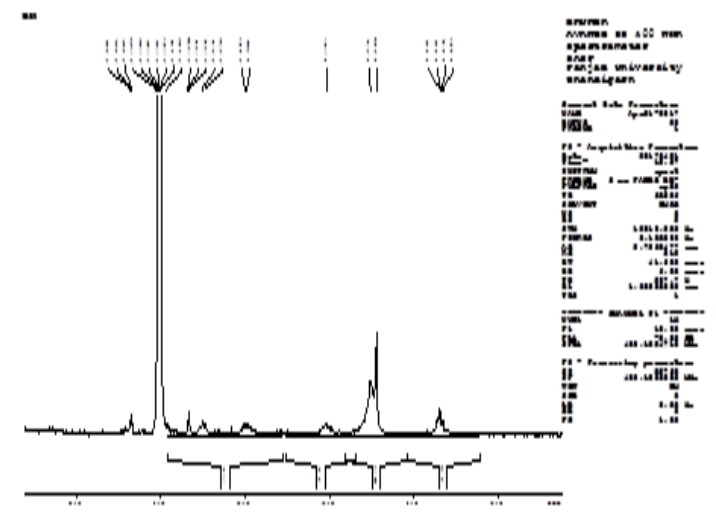

Figure 3: NMR Spectra of Glycine max biopolymer.

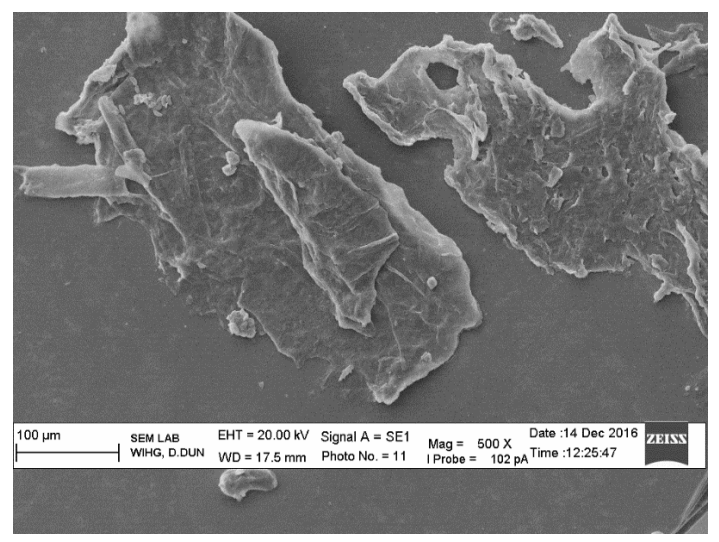

Figure 4: SEM of Glycine max biopolymer. mulations (FGO1-FGO6) was found to be in range of $0.019 \pm 0.012 \mathrm{~mm}$ to $0.037 \pm 0.010 \mathrm{~mm}$.

\section{Surface pH of Formulated Bio-flexy Films}

The Surface $\mathrm{pH}$ of Bio-Flexy films formulations (FGO1-FGO6) was found to be in range of $7.01 \pm 0.03$ to $7.01 \pm 0.02$.

\section{EX-vivo Mucoadhesion Study of Formulated Bio-flexy Films using Capra aegagrus (Goat) Intestinal mucosa}

Formulations (FGO1-FGO6) showed mucoadhesivity for 30-120 $\mathrm{min}$.

\section{Ex-vivo Mucoretention Study of Formulated Bio-flexy Films using Capra aegagrus (Goat) Intestinal mucosa}

Ex-vivo Mucoretention Study revealed that Formulations (FGO1-FGO6) were mucoretentive on Capra aegagrus mucosal surface for time period of 90-210 mins.

\section{Weight Uniformity of Formulated Bio-flexy Films}

The Weight Uniformity of Formulations (FGO1FGO6) was found to be in range of $0.078 \pm 0.05 \mathrm{mg}$ to $0.083 \pm 0.04 \mathrm{mg}$.

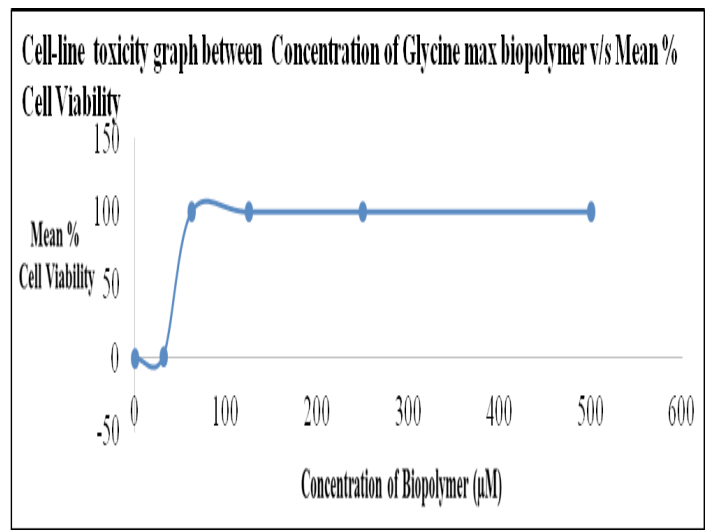

Figure 5: Cell-Line Toxicity Study Data Graph of Glycine max Biopolymer.

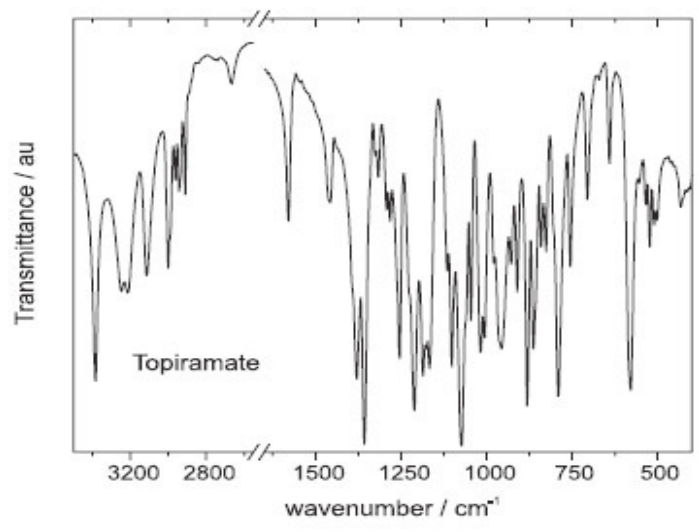

Figure 6: IR Spectra of pure Topiramate. 


\section{Drug Content Uniformity of Formulated Bio-flexy Films}

The Drug Content Uniformity of Formulations (FGO1FGO6) was found to be in range of $72.7 \% \pm 0.50$ to $82.84 \% \pm 0.48$.

\section{Folding Endurance of Formulated Bio-flexy Films}

Folding Endurance of Formulations (FGO1-FGO6) was found to be in range of 117-173.

\section{Swelling Percentage of Formulated Bio-flexy Films}

The Swelling Percentage of nanosized Topiramate loaded Bio-Flexy films containing Glycine max biopolymer (FGO1-FGO6) was found to be in range of $62 \% \pm 0.6$ to $74 \% \pm 0.4$.

\section{Percentage Moisture Uptake of Formulated Bio-flexy Films}

The Formulations (FGO1-FGO6) showed Percentage Moisture Uptake of $2.0 \% \pm 0.13$ to $2.8 \% \pm 0.12$.

\section{In-vitro Release Study of Formulated Bio-flexy Films by Modified M.S. Diffusion Apparatus}

Formulations (FGO1-FGO6) based on the T50\% and T80\% showed drug release pattern of FGO2 (1:1) > FGO6 (1:10) > FGO1 (1:0.5) > FGO4 (1:5)> FGO5 (1:6) > FGO3 (1:3). Based on various evaluation parameters, FGO2 (containing Topiramate: Glycine max biopolymer (1:1)) Bio-flexy film was selected as the Best formulation as it showed significant values of $\mathrm{T}_{50 \%}: 25$ hrs, $T_{80 \%}: 27$ hrs and having $R^{2}=0.9139$, Higuchi Matrix as best fit model, follows Fickian Diffusion (Higuchi Matrix) release mechanism in comparison to other formulations of same biopolymer. (Figure 11) (Table 4)

Formulations (FEO1-FEO6) based on the T50\% and T80\% showed drug release pattern of FEO4 (1:5) > FEO6 (1:10) > FEO5 (1:6)> FEO1 (1:0.5)> FEO2 (1:1) $>$ FEO3 (1:3). various evaluation parameters evaluation parameters, FEO4 (containing Topiramate: Sodium Carboxyl Methyl Cellulose standard polymer (1:5)) Flexy film was selected as the Best formulation as it showed

Table 3: In-vitro Mucoadhesivity of Glycine max biopolymer by Shear Stress Method.

\begin{tabular}{|c|c|c|c|c|c|c|c|c|}
\hline \multirow{2}{*}{ S. No. } & \multirow{2}{*}{$\begin{array}{l}\text { Time } \\
(\min )\end{array}$} & \multicolumn{6}{|c|}{ Concentration of Glycine max biopolymer solutions (\%w/v) } & \multirow{2}{*}{$\begin{array}{c}\text { Sodium CMC } \\
1 \%\end{array}$} \\
\hline & & $1 \%$ & $2 \%$ & $4 \%$ & $6 \%$ & $8 \%$ & $10 \%$ & \\
\hline 1. & $0 \mathrm{~min}$ & $\begin{array}{c}92.38 \\
\text { gm." }{ }^{-2 ., 21}\end{array}$ & $\begin{array}{l}110.84 \\
\text { gm." }{ }^{* *, a 1}\end{array}$ & $\begin{array}{c}124.52 \\
\mathrm{gm} .\end{array}$ & $\begin{array}{c}135.26 \\
\mathrm{gm} .\end{array}$ & $\begin{array}{c}155.45 \\
\text { gm. }\end{array}$ & $\begin{array}{c}187.55 \\
\mathrm{gm} .\end{array}$ & $186.85 \mathrm{gm}$. \\
\hline 2. & $10 \mathrm{~min}$ & $\begin{array}{l}120.33 \\
\text { gm." }\end{array}$ & $\begin{array}{l}130.22 \\
\text { gm." }\end{array}$ & $\begin{array}{c}159.87 \\
\mathrm{gm} .\end{array}$ & $\begin{array}{c}164.02 \\
\mathrm{gm} .\end{array}$ & $\begin{array}{c}210.12 \\
\mathrm{gm} .\end{array}$ & $\begin{array}{c}226.48 \\
\text { gm. }\end{array}$ & $222.84 \mathrm{gm}$. \\
\hline 3. & $20 \mathrm{~min}$ & $\begin{array}{l}140.72 \\
\text { gm. }{ }^{* * *, a 1}\end{array}$ & $\begin{array}{l}170.54 \\
\text { gm." }{ }^{* * *}, \mathrm{a} 1\end{array}$ & $\begin{array}{c}211.78 \\
\mathrm{gm} .\end{array}$ & $\begin{array}{c}224.15 \\
\mathrm{gm} .\end{array}$ & $\begin{array}{c}244.02 \\
\text { gm. }\end{array}$ & $\begin{array}{c}265.72 \\
\text { gm. }\end{array}$ & $260.06 \mathrm{gm}$. \\
\hline 4. & $30 \mathrm{~min}$ & $\begin{array}{l}160.33 \\
\text { gm." }{ }^{* *, a 1}\end{array}$ & $\begin{array}{l}202.47 \\
\text { gm." }{ }^{* *},{ }^{2} 1\end{array}$ & $\begin{array}{c}246.82 \\
\text { gm. }\end{array}$ & $\begin{array}{c}258.14 \\
\text { gm. }\end{array}$ & $\begin{array}{c}266.64 \\
\text { gm. }\end{array}$ & $\begin{array}{c}298.14 \\
\text { gm. }\end{array}$ & $300.04 \mathrm{gm}$. \\
\hline
\end{tabular}

${ }^{* * *}: p<0.05$ as compared to $10 \% \mathrm{w} / \mathrm{v}$ biopolymer; ${ }^{* * *, \text { a1 }}: p<0.05$ as compared to $1 \% \mathrm{w} / \mathrm{v}$ Sodium Carboxyl Methyl Cellulose Standard Polymer Significance level at 0.05, One Way ANOVA using T test calculator

Table 4: Kinetics Release of Topiramate-Glycine max polymer Bio-flexy Films.

\begin{tabular}{|c|c|c|c|c|c|c|c|}
\hline \multicolumn{7}{|c|}{ Table 4: Kinetics Release of Topiramate-Glycine max polymer Bio-flexy Films. } \\
\hline \multirow{2}{*}{ Release Kinetics Analysis Dynamic Method Formulation of Topiramate: Glycine max Bio-Flexy Films } \\
\cline { 2 - 7 } & $\begin{array}{c}\text { Zero } \\
\text { Formulations }\end{array}$ & 1st order & $\begin{array}{c}\text { Higuchi } \\
\text { Matrix }\end{array}$ & Peppas & $\begin{array}{c}\text { Hixon } \\
\text { Crowell }\end{array}$ & Best Fit Model & Mechanism of Action \\
\hline FGO1 (1:0.5) & 0.9186 & 0.9188 & 0.9356 & 0.9478 & 0.9188 & $\begin{array}{c}\text { Peppas } \\
\text { Korsmeyer }\end{array}$ & Anomalous Transport \\
\hline FGO2 (1:1) & 0.8454 & 0.8458 & 0.9139 & 0.8156 & 0.8457 & Higuchi Matrix & $\begin{array}{c}\text { Fickian Diffusion (Higuchi } \\
\text { Matrix) }\end{array}$ \\
\hline FGO3 (1:3) & 0.9647 & 0.9646 & 0.9193 & 0.9569 & 0.9646 & Zero Order & $\begin{array}{c}\text { Fickian Diffusion } \\
\text { (Higuchi Matrix) }\end{array}$ \\
\hline FGO4 (1:5) & 0.8478 & 0.8485 & 0.9216 & 0.9712 & 0.8483 & $\begin{array}{c}\text { Peppas } \\
\text { Korsmeyer }\end{array}$ & $\begin{array}{c}\text { Fickian Diffusion } \\
\text { (Higuchi Matrix) }\end{array}$ \\
\hline FGO5 (1:6) & 0.7802 & 0.7814 & 0.9015 & 0.9715 & 0.7810 & Keppas & $\begin{array}{c}\text { Fickian Diffusion } \\
\text { (Higuchi Matrix) }\end{array}$ \\
\hline FGO6 (1:10) & 0.5834 & 0.5844 & 0.9235 & 0.8242 & 0.5840 & Higuchi-Matrix & $\begin{array}{c}\text { Fickian Diffusion } \\
\text { (Higuchi Matrix) }\end{array}$ \\
\hline
\end{tabular}




\section{Table 5: Kinetics Release of Topiramate-Sodium CMC Flexy Films.}

Release Kinetics Analysis Dynamic Method Formulations of Topiramate: Sodium CMC Flexy Films

\begin{tabular}{|c|c|c|c|c|c|c|c|}
\hline \multirow[t]{2}{*}{ Formulations } & \multicolumn{5}{|c|}{$R^{2}$} & \multirow[t]{2}{*}{ Best Fit Model } & \multirow[t]{2}{*}{ Mechanism of Action } \\
\hline & $\begin{array}{l}\text { Zero } \\
\text { order }\end{array}$ & $1^{\text {st }}$ order & $\begin{array}{l}\text { Higuchi } \\
\text { Matrix }\end{array}$ & Peppas & $\begin{array}{l}\text { Hixon } \\
\text { Crowell }\end{array}$ & & \\
\hline FEO1 (1:0.5) & 0.8809 & 0.8813 & 0.9327 & 0.9761 & 0.8812 & $\begin{array}{l}\text { Peppas } \\
\text { Korsmeyer }\end{array}$ & $\begin{array}{c}\text { Fickian Diffusion } \\
\text { (Higuchi Matrix) }\end{array}$ \\
\hline FEO2 (1:1) & 0.9170 & 0.9172 & 0.9311 & 0.9610 & 0.9171 & $\begin{array}{l}\text { Peppas } \\
\text { Korsmeyer }\end{array}$ & $\begin{array}{c}\text { Fickian Diffusion } \\
\text { (Higuchi Matrix) }\end{array}$ \\
\hline FEO3 (1:3) & 0.8454 & 0.8460 & 0.8947 & 0.9009 & 0.8458 & $\begin{array}{l}\text { Peppas } \\
\text { Korsmeyer }\end{array}$ & $\begin{array}{c}\text { Fickian Diffusion } \\
\text { (Higuchi Matrix) }\end{array}$ \\
\hline FEO4 (1:5) & 0.9049 & 0.9051 & 0.9425 & 0.9698 & 0.9051 & $\begin{array}{l}\text { Peppas } \\
\text { Korsmeyer }\end{array}$ & Anomalous Transport \\
\hline FEO5 (1:6) & 0.8963 & 0.8963 & 0.9319 & 0.9566 & 0.8963 & $\begin{array}{l}\text { Peppas } \\
\text { Korsmeyer }\end{array}$ & $\begin{array}{l}\text { Fickian Diffusion } \\
\text { (Higuchi Matrix) }\end{array}$ \\
\hline FEO6 (1:10) & 0.8989 & 0.8989 & 0.9371 & 0.9614 & 0.8989 & $\begin{array}{l}\text { Peppas } \\
\text { Korsmeyer }\end{array}$ & Anomalous Transport \\
\hline
\end{tabular}

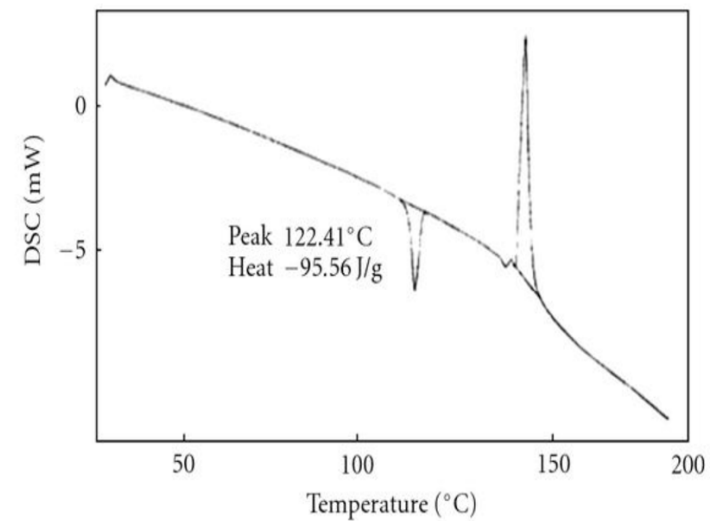

Figure 7: DSC Spectra of pure Topiramate.

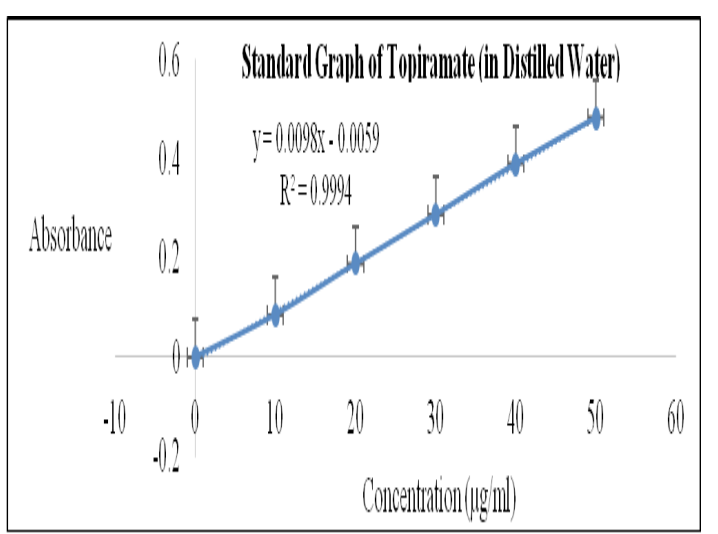

Figure 8 (a): Standard Graph of Topiramate in Distilled Water.

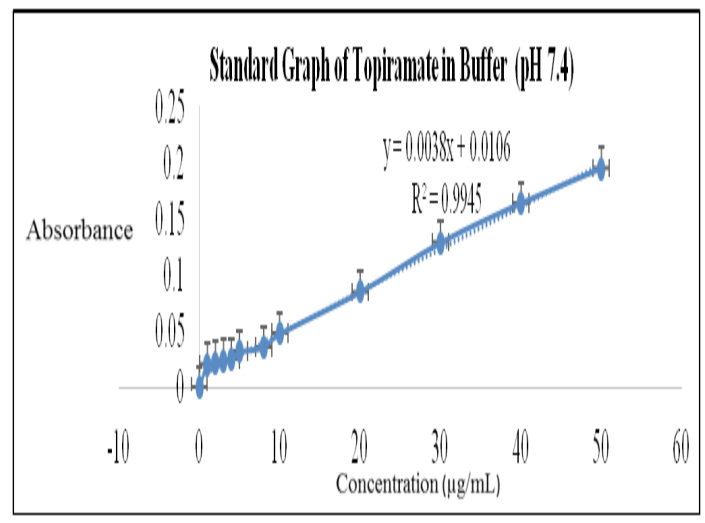

Figure 8 (b): Standard Graph of Topiramate in Phosphate Buffer pH 7.4.

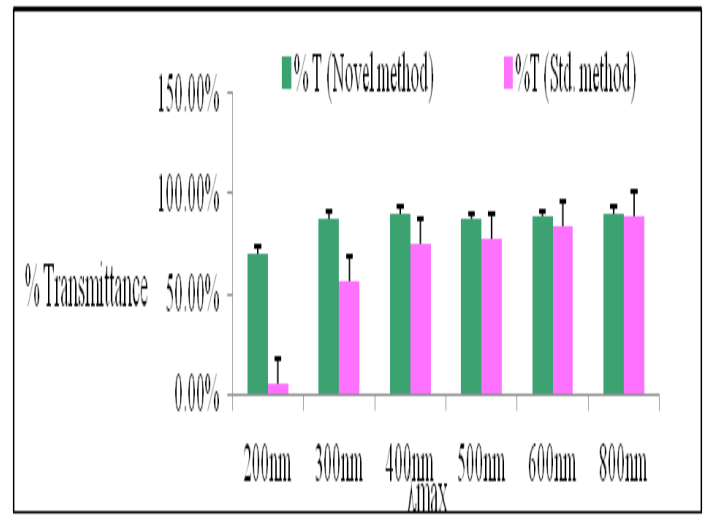

Figure 9: Comparative Graph between \%Transmittance and $\lambda_{\max }$ of nanosized Topiramate (by Novel Sonication and Standard Solvent Evaporation Methods. 


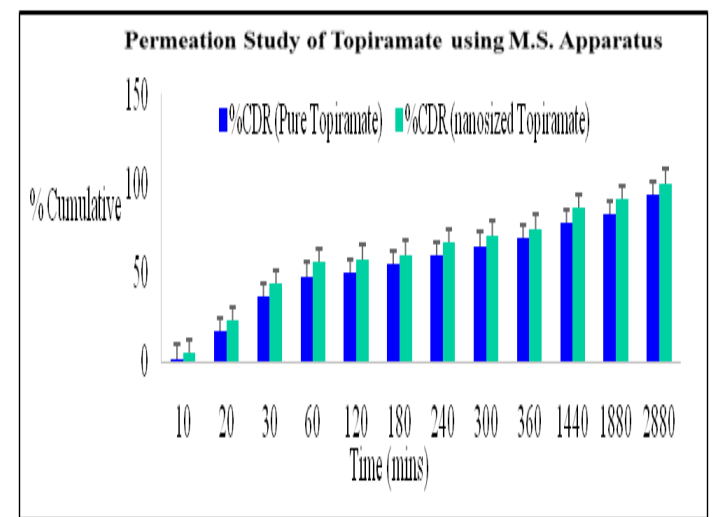

Figure 10: Permeation Study of Topiramate using M.S. Apparatus.

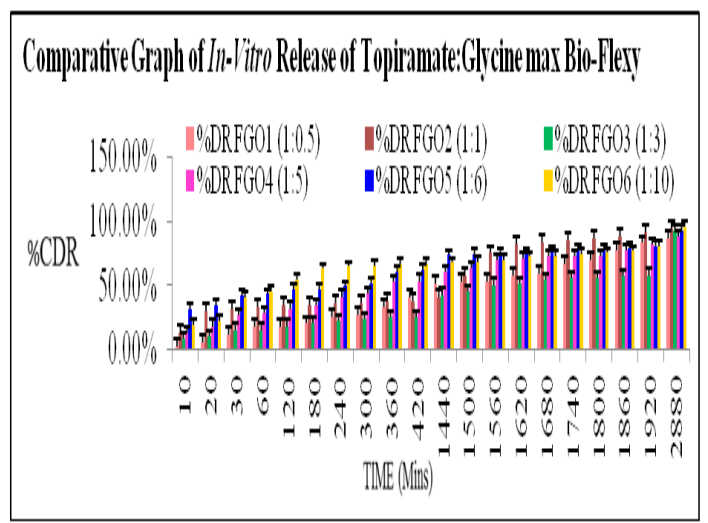

Figure 11: In-vitro Drug Release Graph of nanosized Topiramate loaded Bio-Flexy Films using Glycine max biopolymer by Modified M.S. Diffusion Apparatus.

significant values of $\mathrm{T}_{50 \%}: 10.58 \mathrm{hrs}, \mathrm{T}_{80 \%}: 11.78 \mathrm{hrs}$ and having $R^{2}=0.9698$, Peppas Korsmeyer as best fit model, follows Anomalous transport release mechanism in comparison to other formulations of same standard polymer. (Figure 12) (Table 5)

\section{Stability Studies of Formulated nanosized Drugs loaded Bio-Flexy Films as per ICH Guidelines Q1B}

The stability studies of the formulations revealed stable films. (Figure 13).

\section{CONCLUSION}

In this study bio-flexy films formulations loaded with nanosized Topiramate consisting of novel biopolymer isolated from Glycine max seeds were formulated and evaluated. Biopolymer was biodegradable, inert, showed filmability, mucoadhesivity, mucoretentivity properties. Ratios were chosen at six levels for Drug: Biopolymer (1:0.5 to 1:10) and six levels for Drug: Sodium Carboxyl Methyl Cellulose (1:0.5 to 1:10) for formulating flexyfilms. The biopolymer which was isolated from Glycine

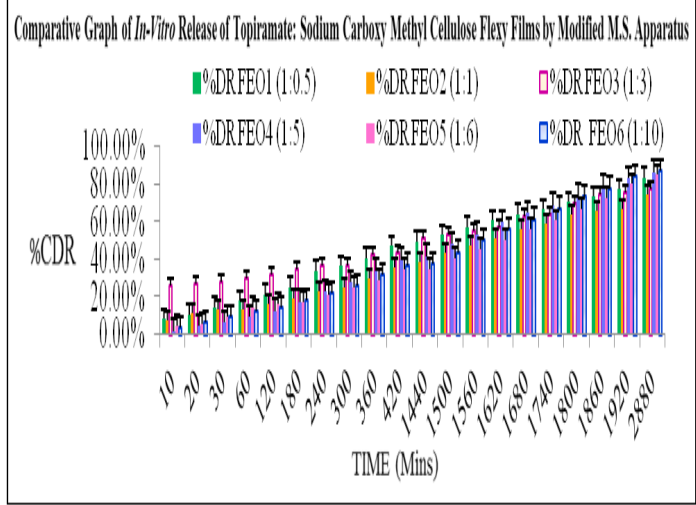

Figure 12: In-vitro Drug Release Graph of nanosized Topiramate loaded Bio-Flexy Films using Sodium Carboxyl Methyl Cellulose standard polymer by Modified M.S. Diffusion Apparatus.

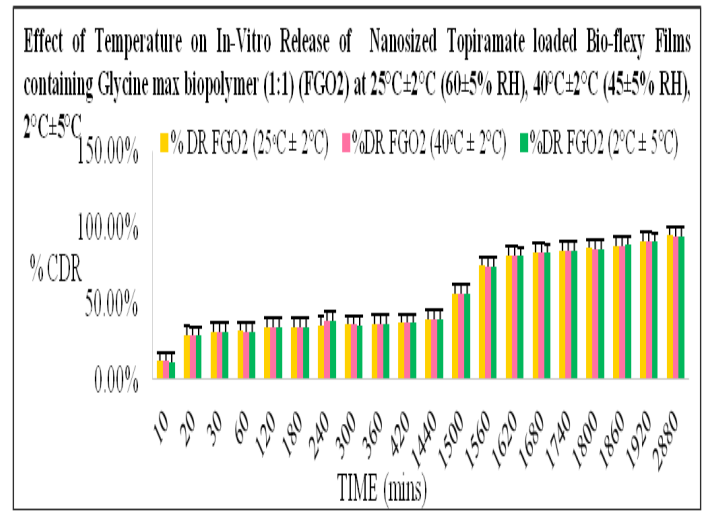

Figure 13: Stability Study Graph of Best Formulations of nanosized Topiramate loaded Bio-Flexy Films containing Glycine max biopolymer.

$\max$ showed percentage yield of $81.06 \% \pm 0.01$. The biopolymer was light yellow in color, odourless, soluble in chloroform, water. Its colour changing point was found to be $218^{\circ} \mathrm{C} \pm 2$. It was tested positive for proteins and carbohydrates, amino acids were not present. Topiramate loaded bio-flexy films containing Glycine max biopolymer (FGO1-FGO6) revealed Thickness: 0.019 $\mathrm{mm} \pm 0.012$ to $0.037 \mathrm{~mm} \pm 0.010$, Surface $\mathrm{pH}: 7.01 \pm 0.03$ to $7.01 \pm 0.02$, ex-vivo Mucoadhesion Time: $30-120 \mathrm{~min}$, ex-vivo Mucoretention Time:90-210 min, Weight Uniformity: $0.078 \pm 0.05$ to $0.083 \pm 0.04$, Drug Content Uniformity: $72.7 \% \pm 0.50$ to $82.84 \% \pm 0.48$, Folding Endurance: 117-173, Swelling Percentage: $62 \% \pm 0.6$ to $74 \% \pm 0.4$, Percentage Moisture Uptake (PTU): $2.0 \% \pm 0.13$ to $2.8 \% \pm 0.12$. The drug release pattern based on the T50\% and T $80 \%$ was found to be FGO2 (1:1) > FGO6 $(1: 10)>$ FGO1 (1:0.5) > FGO4 (1:5)> FGO5 (1:6) > FGO3 (1:3). Based on all evaluation parameters, FGO2 (containing Topiramate: Glycine max biopolymer (1:1)) Bio-flexy film having $R^{2}=0.9139$, Higuchi Matrix as best fit model, follows Fickian Diffusion (Higuchi Matrix) 
release mechanism, T50\%: $25 \mathrm{hr}$., T80\%: $27 \mathrm{hr}$. This is an attempt to deliver antiepileptic molecules to brain at low dose.

\section{ACKNOWLEDGEMENT}

We wish to acknowledge Mr. Anuj Aggarwal (Chairman, DIT University), Prof. K.K. Raina (Vice Chancellor, DIT University) for providing platform for conducting the research work.

\section{CONFLICT OF INTEREST}

The authors declare no conflict of interest.

\section{ABBREVIATIONS}

mm: Millimetre; hr: Hours; Fig: Figure; $\mathbf{c m}^{2}$ : Centimetres Square; mins: Minutes; mL: Millilitre; gm: Grams; mg: Milligram; nm: Nanometer; $\mu \mathrm{g}$ : Microgram; $\boldsymbol{\mu M}$ : Micrometer; d. nm: Diameter in Nanometer; mV: Millivolt; rpm: Revolutions per minute; ${ }^{\circ} \mathrm{C}$ : Degree Centigrade; GABA: Gamma Amino Butyric Acid; KBr: Potassium Bromide; GIT: Gastro Intestinal Tract; API: Active Pharmaceutical Ingredient; U.V.: Ultraviolet Visible Spectroscopy; $\Lambda_{\max }$ : Maximum Absorbance; pKa: Dissociation Constant; $\mathbf{C}_{\max }$ : Maximum Concentration; $\mathbf{T}_{\max }$ : Time to attain peak Concentration; $\mathbf{t}_{1 / 2}:$ Half Life; SEM: Scanning Electron Microscopy; IR: Infra-Red Spectroscopy; DSC: Differential Scanning Calorimetry; NMR: Nuclear Magnetic Resonance Spectroscopy; MTT: 3-(4, 5-Dimethyl Thiazol-2-yl)-5-Diphenyl Tetrazolium Bromide; GIT: Gastro Intestinal Tract; Sodium CMC: Sodium Carboxyl Methyl Cellulose Standard Polymer; FGO1-FGO6: 6 Bio-Flexy Films Formulations of nanosized Topiramate with Glycine max biopolymer in ratios of (1:0.5-1:10); FEO1-FEO6: 6 Flexy Films Formulations of nanosized Topiramate with Sodium Carboxyl Methyl Cellulose Standard poly- mer in ratios of (1:0.5-1:10); $\mathbf{R H}$ : Relative Humidity; CDR: Cumulative Drug Release; T50\%: Time during which $50 \%$ Drug is released; T80\%: Time during which $80 \%$ Drug is released; ICH: International Conference on Harmonization.

\section{REFERENCES}

1. Marra V. Alterations in Vesicular Dynamics at Excitatory and Inhibitory Synapses in Chronic Neocortical epilepsy: Exploring the Balance between Excitation and Inhibition in Epilepsy. Epilepsy Research. 2015.

2. Mishra S. et al. Formulation Characterization and Evaluation of Bioadhesive or dispersible Film of Enalapril Maleate for Soft Palate Drug Delivery. World Journal of Pharmacy and Pharmaceutical Sciences. 2016;5(6):690-8.

3. Satheesh MNV, et al. Recent trends in Oral Trans-mucosal Drug Delivery Systems: An Emphasis on the Soft Palatal Route. Expert Opinion on Drug Delivery. 2012;9(6):629-47.

4. Satheesh MNV, et al. Review on Biopolymers as Novel Bio-Excipients in Drug Delivery System. European Journal of Pharmaceutical and Medical Research. 2017;4(6):247-50.

5. Sharma A, et al. Therapeutic Effects of Glycine max (Soybean). International Journal of Research in Pharmacy and Biosciences. 2015;2(1):22-7.

6. Satheesh MNV. et al. Formulation and Evaluation of Nimesulide Bio-Micro Dwarfs using A Novel Bio-retardant from the Rhizomes of Glycine max. International Journal of Pharmaceutical Technology Research. 2011;3(1):2214.

7. Satheesh MNV, et al. Filed an Indian Patent on Development of flexi Bioadhesive Film loaded with nanosized Zidovudine for Brain specificity via novelistic Soft Palatal route. 2013.

8. Francis $D$, et al. Rapid colorimetric assay for cell growth and survival Modifications the Tetrazolium dye procedure giving improved sensitivity and reliability. Journal of Immunological Methods. 1986;89(2):271-7.

9. Product Information: QUDEXY(TM) XR oral extended-release capsules, Topiramate Oral Extended-Release Capsules. Pushers-Smith Laboratories, Inc. 2014.

10. Kashyap R, et al. Development and Validation of new colorimetric method for the Estimation of Topiramate in Bulk and Dosage Form. International Journal of Pharmacy and Technology. 2012;4(1):3984-99.

11. Satheesh MNV, et al. Soft Palate-A Novel Platform for Transmucosal Delivery of Amikacin. Proceedings of International Conference on Ethnopharmacology and Alternative Medicine, held at Amla Cancer Institute, Trissur, Kerala. 2006.

12. Laxman TS, et al. Development and Validation of an in-vitro and in-vivo Correlation Model in the Rabbit for Topiramate Extended Release Capsules. Indian Journal of Pharmaceutical Sciences. 2016;78(6):732-40.

13. Amin PM, et al. Oral Film Technology: Challenges and Future Scope for Pharmaceutical Industry. International Journal of Pharmacy and Pharmaceutical Research. 2015;3(3):183-203. 


\section{SUMMARY}

- In this study, Bio-flexy films formulations of Topiramate and isolated Glycine max biopolymer were formulated and evaluated for epilepsy treatment. Formulations containing nanosized Topiramate: Glycine max biopolymer (in ratios of 1:0.5, 1:1, 1:3, 1:5, 1:6, 1:10) (FGO1-FGO6) were prepared by solvent casting method. Glycine max biopolymer showed in-built filmability, Mucoadhesive properties, was inert and showed non-reactiveness towards soft palate. Thus, it was used as bio-excipient in formulations. It showed percentage yield: $81.06 \% \pm 0.01$, light yellow, odorless, soluble in chloroform, water and color changing point: $218^{\circ} \mathrm{C} \pm 2$.

- Topiramate loaded bio-flexy films containing Glycine max biopolymer (FGO1-FGO6) revealed Thickness: $0.019 \mathrm{~mm} \pm 0.012$ to $0.037 \mathrm{~mm} \pm 0.010$, Surface $\mathrm{pH}: 7.01 \pm 0.03$ to $7.01 \pm 0.02$, ex-vivo Mucoadhesion Time: 30-120 min, ex-vivo Mucoretention Time:90-210 min, Weight Uniformity: 0.078 \pm 0.05 to $0.083 \pm 0.04$, Drug Content Uniformity: $72.7 \% \pm 0.50$ to $82.84 \% \pm 0.48$, Folding Endurance: $117-173$, Swelling Percentage: $62 \% \pm 0.6$ to $74 \% \pm 0.4$, Percentage Moisture Uptake (PTU): $2.0 \% \pm 0.13$ to $2.8 \% \pm 0.12$. The drug release pattern based on the T50\% and T80\% was found to be FGO2 (1:1) > FGO6 (1:10) > FGO1 $(1: 0.5)>$ FGO4 (1:5)> FGO5 (1:6) > FGO3 (1:3). Based on all evaluation parameters, FGO2 (containing Topiramate: Glycine max biopolymer (1:1)) Bio-flexy film having R2 $=0.9139$, Higuchi Matrix as best fit model, follows Fickian Diffusion (Higuchi Matrix) release mechanism, T50\%: 25 hrs., T80\%: $27 \mathrm{hr}$. Prepared formulations were suitable for Soft Palatal Delivery.

\section{PICTORIAL ABSTRACT}

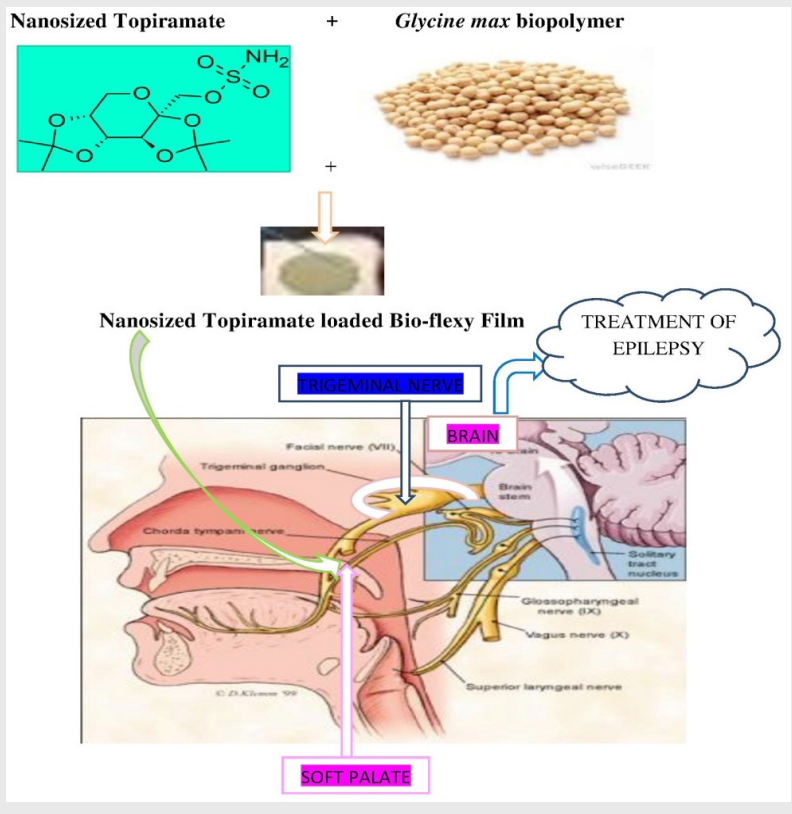

Cite this article: Varshney S, Madhav NVS. Development and Evaluation of Unidirectional Mucoadhesive Bio-Flexy Films Loaded with Nanosized Topiramate using a Novel Biopolymer from Glycine max. Indian J of Pharmaceutical Education and Research. 2020;54(3):618-29. 